\title{
COGNITIVE IMPAIRMENT IN HUMAN CHRONIC CHAGAS' DISEASE
}

\author{
C.A.MANGONE*, R.E.P.SICA*, S.PEREYRA*, O.GENOVESE*, E. SEGURA**, \\ A. RIARTE* , O.P.SANZ*, M.SEGURA*
}

SUMMARY - We proposed to investigate subclinical cognitive impairment secondary to chronic Chagas' disease (CCD). No similar study was previously done. The neuropsychological performance of 45 chronic Chagasic patients and 26 matched controls (age, education place and years of residency in endemic area) was compared using the Mini Mental State Exam (MMSE), Weschler Memory Scale (WMS) and the Weschler Adult Intelligent Scale (WAIS). Non-parametric tests and $\mathrm{Chi} 2$ were used to compare group means and multivariate statistics in two way frequency tables for measures of independence and association of categorical variables with the disease. Results: Chagasic patients showed lower MMSE scores ( $p<.004)$, poor orientation ( $p<.004)$, and attention ( $p<.007)$. Lower WMS MQ were associated with $\mathrm{CCD}(\mathrm{Chi} 25.9 ; \mathrm{p}<.01$; Fisher test $\mathrm{p}<.02)$. Lower WAIS IQ were associated with $\mathrm{CCD}$ (Chi2 $6.3, p<.01$; Fisher test $p<.01)$ being the digit symbol $(p<.03)$, picture completion $(p<.03)$, picture arrangement $(p<.01)$ and object assembly $(p<.03)$ subtests the most affected. The impairment in non-verbal reasoning, speed of information processing, problem solving, learning and sequencing observed in chronic Chagas disease patients resembles the cognitive dysfunction associated with white matter disease.

KEY WORDS: Chagas' disease, cognitive dysfunction, cerebral white matter involvement.

\section{Disfuncion cognitiva en la enfermedad de Chagas cronica humana}

RESUMEN - El objetivo de esta investigacion fue determinar compromiso cognitivo en pacientes con enfermedad de Chagas en estadio cronico. Se estudio el perfil cognitivo de 45 pacientes chagasicos cronicos (CC) y 26 controles apareados por edad, educacion, lugar y tiempo de residencia en area endemica. El Minimental State (MMSE), 1a escala de memoria de Weschler (WMS) y el test de Inteligencia de Weschler (WAIS) han sido utilizados para evaluar ambos grupos. Para el estudio estadistico de los datos se utilizaron pruebas no parametricas, Chi2 y estadistica multivariada en tabla de $2 \times 2$ para medir la association o independencia de variables categoriales con la presencia de enfermedad. Los resultados mostraron que los pacientes alcanzaban score menor que los controles en el MMSE $(\mathrm{p}<0.004)$ debido basicamente a una mas pobre orientacion $(\mathrm{P}<0.004)$ y atencion $(\mathrm{p}<0.007)$. Cocientes bajos de memoria en el WMS se asociaron a la presencia de enfermedad (Chi2 5.9, $\mathrm{p}<0.01$; test de Fisher $\mathrm{p}<0.02$ ). Cocientes bajos de inteligencia en el WAIS se asociaron con la presencia de enfermedad (Chi2 6.3, p<0.01; test de Fisher $\mathrm{p}<0.01)$. Los subtests simbolos digitos ( $\mathrm{p}<0.03)$, completamientos de figuras $(\mathrm{p}<0.03)$, ordenamiento de laminas $(p<0.01)$ y rompecabezas $(p<0.03)$ mostraron mayor compromiso. Estos resultados sugieren disfuncion del razonamiento no verbal, disminucion de la velocidad de procesado de la informacion y dificultad en la resolucion de problemas nuevos, en la habilidad de secuenciacion y en el aprendizaje. Este conjunto de hallazgos sugiere posible compromiso de la sustancia blanca subcortical en estos enfermos. cerebral.

PALAVRA-LLAVE: enfermedad de Chagas, disfuncion cognitiva, compromiso de la substancia blanca

Chagas' disease is a South American trypanosomiasis. In Argentina 30\% of the population is at risk and 5\% is infected. Some reports have shown that chronic Chagas' disease (CCD) affects the peripheral nervous system. Involvement of the alpha spinal motoneurone and peripheral nerve trunks have been described in humans ${ }^{11,13}$. An experimental mouse model, infected with different Trypanosoma cruzi strains, has replicated the clinical observations ${ }^{5,6}$. These last investigations

* Division Neurologia, Hospital Ramos Mejia, Buenos Aires; ** Instituto para el Diagnostico y Tratamiento de la Enfermedad de Chagas Dr. Fatala Chaben, Buenos Aires. Aceite: 5-novembro-1993.

Dr. R. E. P. Sica - Division Neurologia, Hospital Ramos Mejia - Urquiza 609 - 1221 Buenos Aires - Argentina.. 
Table 1. Demographic characteristics of the population.

\begin{tabular}{lcc}
\hline & Patients & Controls \\
\hline \hline Number & 45 & 26 \\
Sex (Male) & $19(42 \%)$ & $10(39 \%) \quad @$ \\
$\begin{array}{l}\text { Age (years) } \\
\begin{array}{l}\text { Education (years) } \\
\text { Residency in } \\
\text { edemic area } \\
\text { (years) }\end{array}\end{array}$ & $36.9 \pm 10.5$ & $33 \pm 10$ \\
\hline
\end{tabular}

Wilcoxon Non Parametric test (No differences between groups). @ (Chi2 statistics). revealed that the spinal motoneurone somae, the posterior root ganglia cells, the nerve axons or their myelin sheets were affected either alone or in combination. Chronic and acute forms of central nervous system (CNS) involvement (Chagas' encephalopathy) have been also described ${ }^{9}$. IgG antineuron and antimyelin antibodies were detected in serum and cerebrospinal fluid in the acute stages as a consequence of an immunologic reaction (local release of neuronal and myelinic antigenic fractions and production of self-antibodies). These immunologic reactions may play an important role in the chronic CNS dysfunction in $\mathrm{CCD}^{10}$.

Although most of the patient's with chronic Chagas' disease look bradyphrenic, not any study has assessed the cognitive performance in them. We have begun to study the CNS in these patients in order to investigate possible involvement of it in the chronic stages of the disease. As part of this research we have proposed a systematic study of the neuropsychological functions to seek subclinical cognitive involvement in these patients. In the present paper we discuss the data of the first 45 patients studied. Partial reports of these findings have been presented elsewhere ${ }^{7.8}$.

\section{MATERIAL AND METHODS}

We studied the neuropsychological performance on 45 patients with chronic Chagas' disease that did not complain on cognitive loss and it was compared with that of 26 matched controls (age, education, place and years of residency in the same geographical area). CCD patients and controls were free of any other systemic or neurologic disorder that may cause cognitive decline.

Previous history of psychiatric disorders, chronic use of neuroteptics or antidepressants and alcohol or any other drug abuse were exclusion criteria for either group.

The Folstein Minimental State (MMSE) ${ }^{3}$, the Weschler Memory Scale (WMS) ${ }^{14}$ and the WAIS global test of Intelligence ${ }^{15}$ were used to score the cognitive performance.

Statistical Analysis. Data were analyzed with the BMDP Statistical Software package. Differences between group means were assessed with the Wilcoxon non-parametric test for continuous variables and the Chi 2 for categorical variables. Multivariate statistics in two way frequency tables were used to obtain measures of association and independence between the categorical variables (WAIS IQ and WMS MQ) and the presence or absence of Chagas' infection.

\section{RESULTS}

Demographic characteristics of the population are shown in Table 1. Special care was taken in matching both groups. Patients and controls were from the same endemic area where they lived on for almost the same period of time. No differences were observed regarding sex, age and education.

Statistical difference $(\mathrm{p}<.004)$ was observed in the MMSE scores between controls (28.8 \pm 1.2$)$ and CCD

Table 2. WAIS scores in patients and controls.

\begin{tabular}{lccc}
\hline & Patients & Controls & $\mathrm{p}$ \\
\hline Information & $6.67 \pm 2$ & $8 \pm 3.2$ & \\
Comprehension & $6.5 \pm 2.5$ & $7.7 \pm 3.2$ & \\
Arithmetics & $6.1 \pm 2$ & $7.1 \pm 2$ & \\
Analogies & $7.7 \pm 3$ & $9 \pm 3$ & \\
Digit span & $6.2 \pm 2.6$ & $7.4 \pm 2.7$ & \\
Vocabulary & $7.2 \pm 1.8$ & $8 \pm 3$ & $<.03$ \\
Digit symbols & $6.2 \pm 2$ & $7.3 \pm 2$ & $<.03$ \\
Picture compl. & $6.2 \pm 1$ & $7.4 \pm 2.7$ & \\
Block design & $7.4 \pm 2.4$ & $8.3 \pm 2.4$ & \\
Picture arrang. & $6.1 \pm 2.7$ & $8 \pm 3.2$ & $<.01$ \\
Object & $6.4 \pm 2.4$ & $8 \pm 3.1$ & $<.03$ \\
assembly & & &
\end{tabular}

Wilcoxon Non Parametric test (differences between groups). Values for each variable are expressed as the $\mathrm{x}+\mathrm{SD}$ 
Table 3. Percentage of the WAIS IQ in the population.

\begin{tabular}{cccc}
\hline WAIS IQ & Percentile & \% Patients & \% Controls \\
\hline$<90$ & 1 to 20 & 85 & 57 \\
$90-100$ & 25 to 75 & 13 & 35 \\
$>100$ & 80 to 95 & 2 & 8 \\
\hline
\end{tabular}

Patients $n=45$. Controls $n=26$.

(27.5 \pm 2.3$)$. The principal differences were observed in orientation (controls $9.7 \pm 0.4 ; \mathrm{CCD} 9 \pm 1.1 ; \mathrm{p}<.007$ ) and attention subtests (controls $4.7 \pm 0.8$; CCD $4.1 \pm 1.3$; p<.004).

The WMS Associated Learning test showed differences $(\mathrm{p}<.002)$ between controls $(11.6 \pm 2.5)$ and $\operatorname{CCD}(9.4 \pm 3.01)$.

Only the Performance subtests of the WAIS showed statistical differences between groups (Table 2). Multivariate analysis in $2 \times 2$ tables showed differences between controls and patients regarding the WAIS IQ and the WMS MQ. Most of the CCD patients had WAIS IQ lower than 90 (Table 3) and 35\% of the controls showed WMS MQ higher than 90 while only $13 \%$ of CCD patients did.

The presence and absence of Chagas' infection was correlated with the WAIS IQ (using 90 as cutoff) in two way frequency tables (Table 4). A significant Pearson Chi2 statistic with a Fisher Exact test rejected the null hypothesis of independence of rows and columns. In $2 \times 2$ tables, the Phi-Cramer coefficient can be interpreted by paying attention to its sign. In this case it is negative; so, the lower values for the categorical variable WAIS IQ (IQ below 90) were associated with the higher code for the categorical variable disease (present $=1$ ).

The Memory Quotient MQ was evaluted in the same way and the null hypothesis of independence also rejected (Table 5).

\section{COMMENTS}

Previous observations have shown that patients with chronic Chagas' disease may have some degree of cognitive impairment ${ }^{1}$. However, none of them could define a cognitive profile in these patients and propose a type of lesion which might underlay the process.

Our findings suggest that chronic Chagas' infection is highly correlated with low cognitive performance. We reduced confounders in the analysis of differences between groups matching

Table 5. Association between WMS MQ and chronic Chagas' infection.

Chagasic infection

1 (Present) 0 (Absent)

\begin{tabular}{cccc}
\hline \hline $\mathrm{W}$ & $\begin{array}{c}\text { Less } \\
\text { than }\end{array}$ & $87 \%$ & $61 \%$ \\
$\mathrm{M}$ & 90 & & \\
$\mathrm{~S}$ & & & \\
$\mathrm{M}$ & $\begin{array}{c}\text { More or } \\
\mathrm{Q}\end{array}$ & $13 \%$ & $39 \%$ \\
\hline
\end{tabular}

Pearson Chi2 5.9, p<.01; Fisher Exact test (2t) $\mathrm{p}<.02$. them by age, education, place and years of residency in the same endemic region.

Familiar, well-learned, and over-practiced knowledge and skills (such as those generally represented by the WAIS Verbal IQ) did not show differences between healthy and infected individuals. Conversely, the non-verbal reasoning and the ability to solve novel and unfamiliar problems, as well as the capacity to plan new strategies (such as those represented in the WAIS Performance IQ) were impaired in the chagasic patients. Among these subtests, those that are timed measures such as picture completion, digit symbol, picture arrrangement and object assembly, were the tests that best distinguished the groups. 
CCD patients had less number responses in a time unit rather than increased number of wrong responses. These observations suggest that the differences between groups relay in the slowness of the patients to accomplish with the proposed tasks.

CCD patients were as able as controls in the final design the cubes but slower. As the cube design subtest did not show differences between groups in the execution of the task we can assume that perception and visuospacial planning were not affected and that impaired speed of information processing may be an important factor explaining the difference. This is also supported by the slow performance observed in the digit symbol task and leaves the impaired speed of information processing as the principal factor of the difference between groups.

The low performance observed in non verbal reasoning, orientation, problem solving and sequencing suggest frontal lobe dysfunction. The impairment in associative learning indicates deficits codifying new information. This neuropsychological picture resembles the reported cognitive dysfunction associated with white matter disease ${ }^{2}$.

This last conclusion is in agreement with previous reports about evoked potentials ${ }^{4}$ that showed slowness of the central conduction time in some CCD patients when tested by somatosensory and auditive paradigms and with recent observations of Segura et al. (personal communication) who found that central reaction time studied with an oddball paradigm was impaired in some of these patients.

\section{REFERENCES}

1. Echeverria H, Gnisci F. Estudios psicologicos en pacientes chagasicos (carta al editor). Rev Neurol Arg 1977, 3:484.

2. Filley C, Frankin G, Heaton R, Rosenberg N. White matter dementia: clinical disorders and implications. NNBN 1989, 1:239-254.

3. Folstein MF, Folstein SE, MacHugh PR. Mini-Mental state: a practical method for grading the cognitive state of patients for the clinician. J Psychiatr Res 1975, 12:189-198.

4. Genovese OM, Sanz OP, Correale J, Garcia Erro M, Sica REP. Cerebral evoked potentials in human chronic Chagas' disease. Arq Neuropsiquiatr 1989, 47:274-278.

5. Gonzalez Cappa SM, Sanz OP, Muller LA, Molina HA, Fernandez J, Rimoldi MT, Sica REP. Peripheral nervous system damage in experimental chronic Chagas' disease. Am J Trop Med Hyg 1987, 36:41-47.

6. Losavio A, Jones MC, Sanz OP, Mirkin G, Gonzalez Cappa SM, Muchnik S, Sica REP. A sequential study of the peripheral nervous system involvement in experimental Chagas' disease. Am J Trop Med Hyg 1989, 41:539-547.

7. Mangone CA, Pereyra S, Genovese O, Segura E, Sica REP. XXXVI Congreso de la Sociedad Argentina de Investigacion Clinica. Mar del Plata, 1991. Medicina 1991, 51:449.

8. Mangone CA, Pereyra S, Genovese O, Segura E, Sica REP. Neurology 1992, 42 (Suppl 3):278.

9. Monteverde DA, Taratuto AL, Lucatelli N. Meningoencefalitis chagasica aguda en pacientes inmunosuprimidos. Rev Neurol Arg 1976, 2:260.

10. Ribeiros dos Santos R, Ramos de Oliveira J, Ross MA. Antibodies to neurons in chronic Chagas' disease. Trans R Soc Trop Med Hyg, 1976, 70:167.

11. Sica REP, Sanz OP, Aristimuto GG, Basso S, Pagano MA, Taratuto AL, Fumo T, Ratusnu AF, Colombi A. Muscle denervation in chronic Chagas' disease. Medicina 1979, 39: 579-588.

12. Sica REP, Filipini D, Panizza M, Fumo T, Basso S, Lazzari J, Molina HA. Involvement of the peripheral sensory nervous system in human chronic Chagas' disease. Medicina 1986 46:662-668.

13. Sica REP, Genovese OM, Garcia Erro M. Peripheral nerve conduction studies in patients with chronic Chagas' disease. Arq Neuropsiquiatr 1991 49:405-408.

14. Weschler D. A standarized memory scale for clinical use. Psychol 1945, 19:87-95.

15. Weschler D. The Weschler Adult Intelligence Scale: edicion adaptada a Buenos Aires (Hector Fernandez Alvarez) Buenos Aires: Paidos, 1988. 